\title{
O CONTEÚDO MÍNIMO DA FUNDAMENTAÇÃO DAS DECISÕES JUDICIAIS NO ORDENAMENTO JURÍDICO BRASILEIRO
}

\section{THE MINIMUM CONTENT OF THE REASONING OF JUDICIAL DECISIONS IN THE BRAZILIAN LEGAL SYSTEM}

\author{
Antônio Rogério Lourencini \\ Universidade Estadual Paulista ‘Júlio de Mesquita Filho’ - Unesp - (Franca, SP, Brasil) \\ Yvete Flávio da Costa \\ Universidade Estadual Paulista ‘Júlio de Mesquita Filho’ - Unesp - (Franca, SP, Brasil)
}

Recebimento: 14 dez. 2017

Aceitação: 12 mar. 2018

\begin{abstract}
Como citar este artigo / How to cite this article (informe a data atual de acesso / inform the current date of access):
LOURENCINI, Antônio Rogério; COSTA, Yvete Flávio da. O conteúdo mínimo da fundamentação das decisões judiciais no ordenamento jurídico brasileiro. Revista da Faculdade de Direito UFPR, Curitiba, PR, Brasil, v. 63, n. 1, p. 161187, abr. 2018. ISSN 2236-7284. Disponível em: <http://revistas.ufpr.br/direito/article/view/56981>. Acesso em: 30 abr. 2018. DOI: http://dx.doi.org/10.5380/rfdufpr.v63i1.56981.
\end{abstract}

\section{RESUMO}

O presente artigo visa a analisar o conteúdo mínimo exigido à fundamentação das decisões judiciais no ordenamento jurídico brasileiro, abordando os diferentes elementos da fundamentação, tais como conceito, características, natureza jurídica, funções endoprocessuais e extraprocessuais desta parte do ato decisório e a classificação da norma constitucional que exige que todas as decisões judiciais sejam fundamentadas. Explana os possíveis conflitos entre o princípio da obrigatória fundamentação e o princípio da garantia à razoável duração do processual, tratado no inciso LXXVIII, do art. $5^{\circ}$, da Constituição Federal, e o princípio da eficiência processual, disposto no caput do art. $8^{\circ}$, do Código de Processo Civil. Aborda as consequências, para a regularidade e validade do processo, da ausência de fundamentação das decisões, à luz do que dispõem as normas do inciso IX, do art. 93, da Constituição Federal, e dos incisos I a VI, do $\S 1^{\circ}$, do art. 489, do Código de Processo Civil.

\section{PALAVRAS-CHAVE}

Decisões judiciais. Fundamentação. Duplo nível de justificação.

\begin{abstract}
The purpose of this article is to analyse the minimum content required to a statement of reasons for judicial decisions in the Brazilian legal system, addressing the different elements of the reasoning, such as concept, characteristics, legal nature, endo-extra procedural functions of this part of the decision-making act and the classification of the constitutional norm which requires all judicial decisions to be well-founded. It explains the possible conflicts between the principle of obligatory grounds and the constitutional principle of the guarantee to a reasonable duration of proceedings, foreseen in item LXXVIII, art. 5, of the Federal Constitution, and the principle of procedural efficiency, set forth in the caput of art. 8, of the Code of Civil Procedure. It addresses the consequences of the lack of reasoning of decisions for the regularity and validity of the process, under
\end{abstract}


the provisions of item IX, art. 93, of the Federal Constitution and of items I to VI, paragraph 1, art. 489, of the Code of Civil Procedure.

\section{KEYWORDS}

Judicial decisions. Statement of reasons. Double level of justification.

\section{INTRODUÇÃO}

O Código de Processo Civil (CPC) (BRASIL, 2015), ao trazer, nos incisos I a VI, do $\S 1^{\circ}$, do art. 489, um rol de situações relativas a quaisquer decisões judiciais que, em ocorrendo, fazem com que estas sejam consideradas não fundamentadas e, portanto, violadoras do inciso IX, do art. 93, da Constituição Federal (CF) (BRASIL, 1988), gera divergência de opiniões entre juristas.

Uma parcela dos magistrados brasileiros não concorda com o fato de o legislador infraconstitucional tratar do tema, e essa discórdia revelou-se explícita quando, em março de 2015, como noticiou Márcia Delgado (2015), três associações de magistrados - a Associação Nacional dos Magistrados da Justiça do Trabalho (Anamatra), a Associação dos Magistrados Brasileiros (AMB) e a Associação dos Juízes Federais do Brasil (Ajufe) - encaminharam pedidos de vetos daqueles dispositivos do CPC à Presidência da República.

A fim de colaborar com a pacificação dessa controvérsia, utilizando-se o método dedutivo de abordagem, a partir da investigação de material doutrinário e normativo, objetiva-se com esta pesquisa entender as razões de ser exigida pelo ordenamento jurídico brasileiro, inclusive com previsão constitucional, fundamentação em todas as decisões judiciais. Ademais, visa-se a compreender os porquês de o legislador processualista ter tratado também de tal dever dos juízes, de modo mais detalhado que o constituinte de 1988, dedicando seis incisos, no $\S 1^{\circ}$, do art. 489, do CPC, para tratar de situações específicas nas quais não se considerará fundamentada qualquer decisão judicial, seja decisão interlocutória, sentença ou acórdão.

\section{OS DIFERENTES ELEMENTOS DA FUNDAMENTAÇÃO DAS DECISÕES JUDICIAIS}

O pressuposto basilar à compreensão da fundamentação das decisões judiciais de que tratam o inciso IX, do art. 93, da CF, e o $\S 1^{\circ}$, do art. 489, do CPC, é o entendimento de que ela envolve questão procedimental e não o mérito do ato decisório. Fundamentar é o ato de explicitar o fundamento, tornar conhecida a ratio decidendi e demais motivos em que se embasa a decisão, e isso se revela pela sanção prevista pela CF para a decisão não fundamentada, qual seja, nulidade.

Ao falar em decisão nula, o constituinte claramente mostra que o vício atinente à 
fundamentação é formal e não material, não significando necessariamente que o direito aplicado ao caso (a ratio decidendi) está incorreto. Se assim o fosse, de acordo com a técnica processual, a decisão não fundamentada mereceria ser reformada, e não anulada.

A anulação e a reforma são meios de desconstituição das decisões judiciais usados para situações incluídas em dois âmbitos distintos. Aos interessados é dado o direito de recorrer tanto para buscar a decretação de nulidade quanto a reforma da decisão atacada, mas em cada situação necessitarão ser indicadas as razões de fato e de direito que justifiquem de modo específico se se busca a nulidade/invalidação ${ }^{1}$ ou a reforma. Isso é válido para os recursos contra qualquer decisão, seja sentença, decisão interlocutória ou acórdão (artigos 1.010, III; 1.016, III; e 1.029, III - todos do CPC). A inadequação ao ordenamento apontada como existente, caso seja reconhecida pelo órgão apreciador do recurso, é que determinará se tecnicamente será caso de reforma ou de anulação da decisão atacada.

Deverá o recorrente buscar a reforma da decisão quando entender que o juiz não julgou corretamente porque aplicou direito diverso do que a justa composição do litígio reclama, mesmo tendo sido observadas todas as exigências processuais e procedimentais. Trata-se de discordância acerca de questão material, questão de fundo. Nesse caso, o recorrente impugna a decisão porque acredita que o juiz cometeu o chamado error in judicando, que, como lecionam Fredie Didier Jr. e Leonardo Carneiro da Cunha (DIDIER JÚNIOR et al., 2016, p. 135), é o equívoco de julgamento, tratando-se de "um dado que investiga no conteúdo da decisão: o juiz decidiu mal, apreciou mal aquilo que lhe foi submetido para ser decidido.”

Diferentemente, o recorrente visará à anulação ou invalidação da decisão, independentemente de concordar com o fundamento jurídico adotado, se entender que na relação jurídico-processual não foram observadas exigências formais, de caráter processual. Não implica necessariamente a afirmação de que há discordância da conclusão jurídica adotada pelo juiz, mas sim que não está de acordo o recorrente em como àquela se chegou. É o caso em que se diz ter ocorrido error in procedendo (erro no procedimento), que, como afirmam Fredie Didier Jr. e Leonardo Carneiro da Cunha (DIDIER JÚNIOR et al., 2016, p. 136), consiste em vício de atividade, ocorrente quando o magistrado deixa de observar norma procedimental, causando prejuízo ao recorrente; os errores in procedendo são concernentes à condução do procedimento, à forma dos atos processuais,

\footnotetext{
${ }^{1}$ O CPC usa a expressão invalidação da decisão em contraposição à reforma da decisão, dando claro entendimento de que invalidar ou anular/declarar nula a decisão tem o mesmo sentido na lei processual, significando ato de desconstituição da decisão por erro procedimental/formal. Isso pode ser verificado nos seguintes dispositivos: $\S \S 2^{\circ}, 3^{\circ}, 5^{\circ}$ e $6^{\circ}$, do art. 304; § 5º do art. 495; inc. III, do art. 1.016 e inc. III, do art. 1.029.
} 
não dizendo respeito ao conteúdo do ato em si. Nessa situação, o recurso atacará vício maculador do devido processo legal.

A partir dessa ideia básica de que a fundamentação se relaciona à forma do ato decisório, antes de se abordar qual o conteúdo mínimo da fundamentação exigido pelo ordenamento jurídico brasileiro às decisões judiciais, serão a seguir apresentados, em linhas gerais, os diferentes elementos da fundamentação.

\subsection{RATIO DECIDENDI E OBITER DICTA}

Como ensina Luiz Guilherme Marinoni (MARINONI; ARENHART; MITIDIERO, 2012, p. 4), o significado de ratio decidendi sempre foi de grande importância nos países de common law, onde os julgados precedentes têm força vinculante e a ratio decidendi é a única parte do ato decisório que efetivamente vincula. Explica Teresa Wambier (2009b, p. 131) que “[...] ratio decidendi é a proposição jurídica, explícita ou implícita, considerada necessária para a decisão. [...] pode ser considerada o núcleo do precedente. Proposições jurídicas que consistem na ratio decidendi do precedente devem necessariamente ser seguidas”. No mesmo sentido leciona Fredie Didier Jr. (2012, p. 12), dizendo que “[...] ratio decidendi são os fundamentos jurídicos que sustentam a decisão; a opção hermenêutica adotada na sentença, sem a qual a decisão não teria sido proferida como foi; trata-se da tese jurídica acolhida pelo órgão julgador no caso concreto”.

Para chegar ao fundamento, o julgador realiza um iter lógico-jurídico envolvendo o caso e o direito a ele aplicável. Nesse caminho, deve o juiz ir expondo o necessário a deixar claros os porquês de ter chegado à conclusão adotada. Esse processo argumentativo-explicativo é a motivação, sendo esta indispensável para que as partes possam ter certeza de que o juiz analisou e levou em consideração todos os argumentos fáticos e jurídicos que circundaram o processo, ficando claro que a ratio decidendi não foi obtida sem a avaliação de todos os fatores a ela contrários, bem como para que o órgão apreciador de eventual recurso também conheça dos porquês motivadores do fundamento adotado pelo juiz.

Analisar todos os argumentos que, em tese, são aptos a derrubar o fundamento adotado no processo é dever do juiz há tempos apontado pela doutrina. Ada Pellegrini Grinover (1992, p. 233234) considera que tal obrigação do órgão julgador é garantia do direito das partes em influir de modo concreto na formação do convencimento do juiz, pois é na motivação que se vê se o juiz realmente analisou todos os argumentos e se levou em conta todas as provas produzidas no processo.

Se o juiz, como regra, examina mais de um argumento das partes, já que o processo se 
desenvolve em contraditório, é certo que a ratio decidendi será contrária a pelo menos um daqueles. E, ao deixar de aplicar argumento invocado por qualquer das partes como direito que deve incidir no caso concreto, precisa o juiz apresentar as justificativas para tanto, demonstrando que todas as alegações das partes, favoráveis ou contrárias à ratio decidendi, foram levadas em conta para a formação da conclusão do ato decisório.

Todos os fatos e fundamentos jurídicos que integram o processo e são objetos da argumentação do juiz na motivação, mas por ele não são considerados como fundamento nuclear do direito incidente na causa são chamados de obiter dicta ou gratis dicta. Descreve Luiz Guilherme Marinoni (MARINONI; ARENHART; MITIDIERO, 2012, p. 9) que a distinção entre obiter dictum (singular do plural obiter dicta) e ratio decidendi sempre foi de muita importância para o common law, e isso se deve à valorização dos fundamentos decisórios, aspecto peculiar da tradição jurídica anglo-saxônica.

O conceito de obiter dicta ou gratis dicta é trazido por Teresa Wambier (2009b, p. 131), dizendo a professora que "Esses termos significam literalmente: o que é dito para morrer, o que é dito por nada, inutilmente. Tudo o que é dito numa decisão e que não integra a ratio decidendi é obiter dicta, e o que é dito obiter dicta tem um peso meramente persuasivo”. Também nesse sentido, Fredie Didier Jr. (2012, p. 13) leciona que obiter dicta "consiste nos argumentos que são expostos apenas de passagem na motivação da decisão, consubstanciando juízos acessórios, provisórios, secundários, impressões ou qualquer outro elemento que não tenha influência relevante e substancial para a decisão".

Vê-se, portanto, que os obiter dicta não integram a ratio decidendi, mas são expostos no processo motivacional do juiz para que os interessados tomem conhecimento de que foram levados em conta todos os argumentos fáticos e jurídicos, todas as provas produzidas, todas as teses aventadas, que poderiam de algum modo ter sido a razão de uma decisão diferente, mas restaram justificadamente não adotados pelo juiz. Nessa perspectiva, apesar de literalmente significar “o que é dito para morrer” e de seus elementos não influenciarem substancialmente para a decisão, os obiter dicta são componentes legitimadores democráticos de qualquer decisão judicial, já que representam a garantia de que o contraditório construído no processo não se resume apenas à oportunidade de as partes se manifestarem contrárias aos argumentos adversos ao direito por elas pleiteado, mas significa também que todos os fundamentos fáticos e jurídicos por aquelas colocados como razão de seu direito, mesmo que considerados inaplicáveis ao caso concreto pelo Poder Judiciário, serão analisados e justificadamente postos de lado.

O direito processual, como ensina Marcus Gonçalves (2016, p. 37-38), passa a ser visto 
como ramo autônomo da ciência jurídica quando se entende que a relação jurídico-processual ganha um integrante que não figura na relação jurídica de direito material geradora do conflito de interesses que desembocou no ajuizamento do processo, qual seja, o Estado-juiz, de forma que o diálogo deste, nos atos decisórios, deve demonstrar às partes que os argumentos delas não são como poeira ao vento que se tornou invisível ao longo do desenvolvimento processual, mas são considerados na formação da decisão. A propósito, uníssonos a isso descrevem Nelson Nery Júnior e Rosa Nery (2015, p. 1.153): “Afirma-se hoje que o juiz também participa do contraditório, pois deve demonstrar que as alegações das partes, somadas às provas produzidas, efetivamente interferiram no seu convencimento”. Teresa Wambier (2009a, p. 57) também entende ser de difícil compreensão que em outros tempos concebeuse o princípio do contraditório de modo diferente: “Que sentido tem, de fato, dar-se à parte o direito de informar-se e de reagir, se ao juiz for dado pura e simplesmente ignorar o material produzido pela atividade das partes?”

Esse dever do juiz é a garantia de que o trabalho despendido pelas partes no exercício do ônus de influenciá-lo foi conhecido e analisado. Como explica Michele Taruffo (2015, p. 340), “É evidente, de fato, que o direito das partes de influir sobre a decisão seria garantido de modo assaz fraco se não fosse possível estabelecer, mediante a motivação, se e de que modo essa influência se verificou ou por quais razões essa não se ocorreu”.

A exigência de o juiz motivar as decisões judiciais dessa forma demonstra que o contraditório não tem caráter meramente linear, mas se eleva a um patamar triangular, envolvendo as partes e o juiz: se às partes incumbe o ônus de convencer o juiz de que os argumentos de seu litigante não merecem guarida, ao juiz a lei delega o dever de justificar os porquês de ter desconsiderado os argumentos de ambas as partes que, em tese, mudariam o dispositivo da decisão.

\subsection{MOTIVOS FUNDANTES}

Os motivos fundantes da fundamentação representam um ponto de intersecção entre a motivação e a fundamentação stricto sensu da decisão. São, pois, os argumentos de fato ou de direito diretamente ligados à norma que incidirá sobre a decisão. Eles integram a ratio decidendi, diferenciando-se dos obiter dicta que, como já dito, não a compõem, mas possuem a essencial função acessória de indicar o caminho lógico-jurídico trilhado pelo julgador até o motivo fundante.

Por exemplo, se em processo de execução ou cumprimento de sentença o executado requerer a liberação de imóvel penhorado, alegando tratar-se de bem de família, portanto impenhorável de acordo com o art. $1^{\circ}$, da Lei ${ }^{\circ}$ 8.009/90 (BRASIL, 1990), o juiz, em qualquer caso, deverá decidir 
apontando pelo menos um motivo fundante e um motivo secundário.

Se deferir o requerimento, o motivo fundante será a comprovação de que realmente se trata de bem impenhorável, por exemplo, porque é o único imóvel utilizado pelo devedor e sua família para moradia permanente, estando amparado pelo caput do art. $5^{\circ}$, da Lei $n^{0} 8.009 / 90$, e os obiter dicta serão aquilo que foi logicamente exposto para firmar tal conclusão, como, por exemplo, ter o devedor apresentado certidões negativas dos cartórios de registro de imóveis da localidade, indicando ser o único imóvel de seu patrimônio.

Se indeferir, o motivo fundante consistirá no fato de que o bem se sujeita à execução, conforme previsto no art. 832, do CPC, porque não está elencado entre os que a lei considera impenhoráveis ou inalienáveis, e os motivos acessórios serão os que indicarão a não comprovação do alegado, como no caso de o juiz argumentar que o exequente trouxe aos autos certidão de que o executado possui outro imóvel de menor valor que o penhorado, devendo incidir ao caso a norma do parágrafo único, do art. $5^{\circ}$, da Lei ${ }^{\circ} 8.009 / 90$.

A seguir, apresenta-se quadro ilustrativo do exemplo supracitado.

Quadro 1 - Exemplos de obiter dicta, motivo fundante e incidência normativa

Exemplo em requerimento do executado visando à liberação de imóvel penhorado, alegando tratar-se de bem de família, portanto impenhorável

\begin{tabular}{|c|c|c|}
\hline $\begin{array}{c}\text { Elementos } \\
\text { fundamentatórios }\end{array}$ & $\begin{array}{l}\text { Fundamentação em decisão } \\
\text { que defere o requerimento }\end{array}$ & $\begin{array}{l}\text { Fundamentação em } \\
\text { decisão que indefere o } \\
\text { requerimento }\end{array}$ \\
\hline $\begin{array}{l}\text { Motivos acessórios ou } \\
\text { secundários } \\
\text { (Obiter dicta) }\end{array}$ & $\begin{array}{l}\text { Razões lógico-jurídicas da } \\
\text { comprovação do motivo } \\
\text { fundante (ex.: apresentação } \\
\text { de certidões negativas de } \\
\text { propriedade de outros } \\
\text { imóveis) }\end{array}$ & $\begin{array}{l}\text { Razões lógico-jurídicas da } \\
\text { não comprovação de que o } \\
\text { bem é elencado pela lei } \\
\text { como bem de família (ex.: } \\
\text { ter o exequente } \\
\text { apresentado certidão de } \\
\text { que o executado possui } \\
\text { outro imóvel de menor } \\
\text { valor que o penhorado) }\end{array}$ \\
\hline Motivo fundante & $\begin{array}{l}\text { Comprovação de que o bem } \\
\text { é elencado pela lei como } \\
\text { impenhorável (ex.: único } \\
\text { imóvel de moradia da família) }\end{array}$ & $\begin{array}{l}\text { O bem se sujeita à } \\
\text { execução }\end{array}$ \\
\hline Incidência normativa & $\begin{array}{l}\text { Norma que dispõe sobre a } \\
\text { impenhorabilidade do bem } \\
\text { de família }\end{array}$ & $\begin{array}{l}\text { Norma que dispõe sobre a } \\
\text { penhorabilidade de bens } \\
\text { do devedor }\end{array}$ \\
\hline
\end{tabular}

Fonte: os autores. 


\section{O CONTEÚDO MÍNIMO DA FUNDAMENTAÇÃO DAS DECISÕES JUDICIAIS NO ORDENAMENTO JURÍDICO BRASILEIRO}

Já abordados os diferentes elementos da fundamentação, cabe agora verificar quais deles necessariamente devem compor a fundamentação das decisões judiciais nos termos do inc. IX, do art. 93, da CF.

A questão, relevante por essência por envolver norma constitucional cogente, ganhou ainda mais pertinência com a entrada em vigor da Lei n 13.105, de 16 de março de 2015 - o novo Código de Processo Civil -, que trouxe nos incisos I a VI, do $\S 1^{\circ}$, de seu art. 489, uma explanação ilustrativa do mínimo necessário ao conteúdo fundamentatório das decisões judiciais, servindo de detalhamento exemplificativo colaborador da revelação da amplitude daquele.

Logo à frente, será trazida a distinção entre fundamentação lato sensu e fundamentação stricto sensu, o que é essencial para que seja entendido qual o conteúdo mínimo dessa parte argumentativa da decisão. Contudo, antes disso, é importante que reste explicado qual espécie de norma constitucional é a do inciso IX, do art. 93, da CF, sua natureza jurídica e as funções que a fundamentação constitucionalmente exigida exerce aos integrantes da relação jurídico-processual e à sociedade em geral.

\subsection{CLASSIFICAÇÃO DA NORMA CONSTITUCIONAL QUE OBRIGA À FUNDAMENTAÇÃO}

A norma que determina a obrigatoriedade de fundamentação de todas as decisões judiciais vem prevista na parte inicial do inciso IX, do art. 93, da CF, e para categorizá-la serão usados como parâmetro os ensinamentos de José Afonso da Silva, que classificou as normas constitucionais quanto à aplicabilidade destas, afirmando existirem três espécies: as de eficácia plena, as de eficácia contida e as de eficácia limitada. Com sucinto esclarecimento sobre essa divisão, pode-se abstrair dos ensinamentos de José Afonso da Silva (2009, p. 82-83) que normas de eficácia plena são as que receberam do constituinte normatividade suficiente para incidir direta e imediatamente sobre a matéria de que cuidam, produzindo ou tendo a possibilidade de produzir todos os seus efeitos desde o início da vigência da Constituição; as de eficácia contida, por sua vez, apesar de também serem aptas a produzir todos os seus efeitos desde a entrada em vigor da Constituição, possibilitam que o legislador infraconstitucional restrinja seus efeitos a certas circunstâncias; já as de eficácia limitada são aquelas sobre as quais o constituinte não tratou, por qualquer motivo, de forma suficiente a lhes 
permitir a produção de todos os efeitos essenciais desde logo, deixando que o legislador infraconstitucional ou outro órgão do Estado crie regras que bastem para isso.

Dados esses conceitos, resta inequívoco que a norma do inciso IX, do art. 93, da CF, na parte em que obriga à fundamentação, enquadra-se no grupo das normas constitucionais de eficácia plena, já que o constituinte não trouxe margem alguma para que o legislador infraconstitucional ou qualquer outro órgão estatal restrinja sua eficácia, tampouco tratou de forma insuficiente da matéria que lhe constitui objeto, de modo que ela passou a produzir todos os seus efeitos logo no início de sua vigência.

Segundo o citado dispositivo constitucional, com redação dada pela Emenda Constitucional $n^{\circ} 45 / 2004$,

IX todos os julgamentos dos órgãos do Poder Judiciário serão públicos, e fundamentadas todas as decisões, sob pena de nulidade, podendo a lei limitar a presença, em determinados atos, às próprias partes e a seus advogados, ou somente a estes, em casos nos quais a preservação do direito à intimidade do interessado no sigilo não prejudique o interesse público à informação (BRASIL, 1988).

Nota-se que a primeira parte do texto normativo constitucional, a qual trata da fundamentação das decisões judiciais, é singela, clara e determinante, não dando qualquer margem a restrições futuras. Apenas é permitido ao legislador infraconstitucional limitar a eficácia da publicidade dos julgamentos, como consta na parte final da norma, mas não pode ser feito isso em relação à obrigatoriedade de fundamentação. Por isso, enquanto a publicidade dos julgamentos é norma de eficácia contida, a obrigatória fundamentação das decisões judiciais é norma de eficácia plena.

\subsection{A FUNDAMENTAÇÃO DAS DECISÕES JUDICIAIS: DIREITO FUNDAMENTAL DE NATUREZA PROCESSUAL}

Segundo o $\S 1^{\circ}$, do art. $5^{\circ}$, da Constituição Federal (BRASIL, 1988), “as normas definidoras dos direitos e garantias fundamentais têm aplicação imediata”. E, seria a obrigatoriedade de fundamentação das decisões judiciais um direito fundamental? A resposta é positiva. Ao inserir tal dever aos juízes e tribunais, o constituinte colocou-o no rol dos direitos fundamentais dos jurisdicionados. Trata-se, pois, de verdadeiro princípio constitucional. Um princípio de tal relevância que tende à plenitude.

Apesar de ser certo que não existe princípio pleno, que não admita limitações (já que, em caso de choque com outro princípio, a solução amplamente adotada pela doutrina e jurisprudência, 
com arrimo jusfilosófico em autores como Ronald Dworkin e Robert Alexy, é o uso da técnica da ponderação, na qual se verifica a particularidade do caso concreto e o grau de incidência dos princípios conflitantes na situação, aplicando-os proporcionalmente sem que um exclua o outro²), vêse que o princípio da obrigatoriedade de fundamentação das decisões judiciais não esbarra em praticamente nenhum outro princípio, com exceção de dois: o da garantia da razoável duração do processo, previsto no inciso LXXVIII, do art. 5º da CF, e o princípio da eficiência, expresso no art. $8^{\circ}$, do CPC, conflitos esses de relevância tamanha que serão discutidos em subseção específica deste artigo.

Fora disso, a obrigatória fundamentação das decisões judiciais não é apta a eliminar nenhum outro princípio. Ora, qual princípio poderá ser lesado pelo fato de o juiz fundamentar sua decisão? Por análise lógica, a resposta haverá de ser a de que, se o juiz esmiuçar as justificativas de sua decisão, dizendo até mesmo o desnecessário, tenderá a perder precioso tempo decidindo, quando, diante da realidade brasileira, há milhares de outros processos à espera de sua decisão, desfavorecendo assim a celeridade e a eficiência processual. Ademais, não há qualquer outra complicação.

A fundamentação obrigatória das decisões judiciais é direito fundamental de natureza processual, não se confundindo, como já abordado, com o direito adotado pelo juiz como incidente ao caso. Nesse aspecto, assemelha-se aos princípios do contraditório e da ampla defesa, previstos no inc. LV, do art. $5^{\circ}$, da CF, e é elemento essencial à existência do devido processo legal. De nada adiantará o juiz permitir a participação das partes no processo, produzindo provas e expondo as razões do direito alegado, se no momento de decidir não apresentar ele fundamentação adequada.

\subsection{A OBRIGATÓRIA FUNDAMENTAÇÃO VERSUS A GARANTIA DA RAZOÁVEL DURAÇÃO DO PROCESSO E O PRINCÍPIO DA EFICIÊNCIA}

Como indicado na introdução deste artigo, três associações de juízes, Anamatra, AMB e Ajufe, encaminharam, em 2015, à Presidência da República, pedidos de vetos de dispositivos do CPC que tratam da fundamentação das decisões judiciais.

Entre os argumentos utilizados para tais pedidos, cumpre destacar os referentes aos vetos que se queriam para os incisos III, IV e V, do $\S 1^{\circ}$, do art. 489, do CPC. Em nota pública, a Anamatra, por meio de seu presidente, Paulo Luiz Schmidt (2015), afirmou que as normas neles contidas

\footnotetext{
${ }^{2}$ Cf., nesse sentido: BRASIL. Superior Tribunal de Justiça. Voto no REsp n ${ }^{0} 706.769$ / RN. Relator: Ministro Luis Felipe Salomão. Brasília, 12 mar. 2009. Diário da Justiça Eletrônico. Disponível em: <https://goo.gl/YMFYQ6>. Acesso em: 11 dez. 2017.
} 
impactarão severamente, de maneira negativa, “[...] na gestão do acervo de processos [...] e na própria produção de decisões judiciais em todas as esferas do país, com repercussão deletéria na razoável duração dos feitos (artigo 5º LXXVIII, da CRFB), [...]”.

Os incisos I a VI, do $\S 1^{\circ}$, do art. 489, do CPC, dispõem que:

$\S 1^{\circ}$ Não se considera fundamentada qualquer decisão judicial, seja ela interlocutória, sentença ou acórdão, que:

I - se limitar à indicação, à reprodução ou à paráfrase de ato normativo, sem explicar sua relação com a causa ou a questão decidida;

II - empregar conceitos jurídicos indeterminados, sem explicar o motivo concreto de sua incidência no caso;

III - invocar motivos que se prestariam a justificar qualquer outra decisão; IV - não enfrentar todos os argumentos deduzidos no processo capazes de, em tese, infirmar a conclusão adotada pelo julgador;

V - se limitar a invocar precedente ou enunciado de súmula, sem identificar seus fundamentos determinantes nem demonstrar que o caso sob julgamento se ajusta àqueles fundamentos; VI - deixar de seguir enunciado de súmula, jurisprudência ou precedente invocado pela parte, sem demonstrar a existência de distinção no caso em julgamento ou a superação do entendimento. (BRASIL, 2015).

Em análise a tais dispositivos, resta inequívoca a intenção legislativa de expressamente dar como nula a decisão judicial abstrata, aquela que usa termos vagos, imprecisos, indeterminados, cabíveis em circunstâncias inúmeras e que não deixa claro se o juiz analisou substancialmente o caso sub judice.

Sem dúvida, algum tempo gastará o juiz escrevendo os motivos concretos presentes no caso que justificam o direito aplicado na decisão, que mostram que se levaram em conta todos os argumentos presentes na relação jurídico-processual aptos a, em tese, levar a outra solução jurídica e também, se for o caso, explicando por que a situação concreta se encaixa a enunciado de súmula adotada como incidência normativa à questão. Mas, será esse tempo um elemento maculador dos princípios da garantia da razoável duração do processo ou da eficiência?

Para se responder a essa indagação, deve-se voltar a atenção para o fato de que os três princípios envolvidos, quais sejam, a obrigatória fundamentação, a garantia da razoável duração do processo e a eficiência processual são direitos dos integrantes da relação jurídico-processual cuja efetivação é imprescindível para que haja o devido processo legal de que trata o inciso LIV, do art. $5^{\circ}$, da CF. E, por serem princípios, devem caminhar juntos sem que um exclua o outro, sob pena de afronta a essa norma constitucional. Assim, a solução será a observância aos três, fazendo-se com que todos sejam respeitados pelo menos no mínimo a satisfazer a devida legalidade do processo.

Tratando dessa necessidade de não abandono, em prol da celeridade processual, ao conteúdo mínimo da fundamentação, sob pena de afronta a direito fundamental, Adriano Cesar Felisberto e Celso Hiroshi Iocohama (2010, p. 129) descrevem que, especificamente sobre isso no âmbito dos 
Juizados Especiais Cíveis Estaduais e Federais, criados, respectivamente, pelas Leis $\mathrm{n}^{\circ}$ 9.099/95 (BRASIL, 1995) e $\mathrm{n}^{0}$ 10.259/01 (BRASIL, 2001), em que pese ser a pacificação social atrelada a uma resposta rápida e justa do Estado pelo Poder Judiciário, “[...] para se alcançar uma decisão justa, não pode o sistema processual abstrair-se de determinadas regras já consagradas como fundamentais no ordenamento jurídico, devendo ficar asseguradas as garantias constitucionais dos cidadãos”.

Tendo isso em vista, para que não haja anulação de nenhum dos três princípios, será necessário que o juiz tenha em mente quais elementos essencialmente compõem a fundamentação das decisões judiciais nos termos do inc. IX, do art. 93, da CF. Pois, se esse conteúdo mínimo constitucionalmente determinado não estiver presente na decisão, de nada valerão celeridade e eficiência processuais, pois se terá anulado o princípio da obrigatória fundamentação, sendo nulo o pronunciamento decisório.

Por outro lado, a celeridade e a eficiência processual também não podem ser abandonadas pelo Poder Judiciário sob o manto do tempo gasto com a fundamentação das decisões. Afinal, de nada adiantará uma decisão redigida em muitas laudas, detalhada, esmiuçadora de todos os argumentos possíveis envolvendo as provas processuais se, em decorrência disso, o processo perdurar por anos, frustrando seu caráter instrumental à consecução do direito material que poderá, ao longo do tempo, ter perdido seu sentido em razão de um reconhecimento tardio do direito.

Com razão, a Escola Nacional de Formação e Aperfeiçoamento de Magistrados (2015, p. 1), no seminário O Poder Judiciário e o novo CPC, aprovou o Enunciado n ${ }^{\circ}$ 10, descrevendo que “A fundamentação sucinta não se confunde com a ausência de fundamentação e não acarreta a nulidade da decisão se forem enfrentadas todas as questões cuja resolução, em tese, influencie a decisão da causa.” Se for sucinta, mas trouxer o conteúdo mínimo a deixar explicitamente conhecido o iter lógico-jurídico que levou ao dispositivo da decisão, a fundamentação não só não padecerá de vício como também mostrará virtude do juiz, que terá sabido ser conciso dizendo o necessário.

É pesada a carga de trabalho a que cada juiz brasileiro está submetido. Essa é uma verdade tão clara na prática forense que nem se necessitaria de um levantamento matemático para tal afirmação, mas, para demonstrar essa notoriedade, têm-se os dados do Conselho Nacional de Justiça (BRASIL, 2017, p. 60-66), os quais evidenciam que em 2016 os 18.011 (dezoito mil e onze) magistrados brasileiros em atividade proferiram 30.800 .000 (trinta milhões e oitocentas mil) decisões. Ou seja, foram em média 1.710 (mil setecentas e dez) decisões anuais por magistrado, o que representa quase 5 (cinco) decisões por dia, desconsiderando-se feriados, férias e recesso forense. Veja-se, está se falando somente das decisões, sem incluir os despachos, todas aquelas devendo ser proferidas com fundamentação. E, diante dessa quantidade expressiva de processos para decidir, será 
prejudicial ao devido processo legal o gasto de longo tempo com dizeres desnecessários nas decisões, com argumentações rebuscadas que extrapolem em demasia aquilo que necessariamente deve estar contido na fundamentação de acordo com o ordenamento jurídico.

Diante desses fatores, revela-se de suma importância que o juiz, para possibilitar a efetividade do direito material, privilegiando a celeridade e a eficiência, sem, contudo, proferir decisão nula por falta de fundamentação, finque seu pensamento, no momento de fundamentar, em usar como parâmetros as situações previstas nos incisos I a VI, do § $1^{\circ}$, do art. 489, do CPC, para que não incorra nas faltas ali constantes que se resumem a fundamentação genérica; mas que, também, não perca excessivo tempo dizendo coisas que extrapolam demasiadamente o necessário a afastar todos os argumentos deduzidos no processo capazes de, em tese, infirmar a conclusão adotada. Ou seja, sem suprimir as essenciais justificativas que devem compor a fundamentação na função de obiter dicta, deve o julgador prezar também pela razoável duração do processo.

\subsection{FUNÇÕES DA FUNDAMENTAÇÃO NO ESTADO DEMOCRÁTICO DE DIREITO}

A exigência de fundamentação das decisões judiciais guarda correspondência com fatores de ordem ideológica, sociológica e política. Olhando por esse ângulo, é essencial a atenção ao fato de que a atual CF descreve, respectivamente, no caput e no parágrafo único, de seu art. $1^{\circ}$, que a República Federativa do Brasil se constitui em Estado Democrático de Direito e que é do povo que emana o poder.

Assim, a análise de quais funções deve assumir a fundamentação das decisões judiciais no Brasil precisa perpassar inevitavelmente pelos ideais democráticos, já que, como qualquer outro elemento integrante de ato do Poder Público, deve àqueles estar submetida, ainda mais pela expressiva importância das decisões judiciais, que são o meio específico de manifestação do Poder Judiciário no exercício de sua função típica: solucionar com imperatividade e definitividade conflitos de interesse.

Nesse sentido, por exemplo, ao tecer comentários sobre o art. 111, da Constituição da República da Itália de 1947 (ITÁLIA, 2012, p. 56), o qual, entre outras disposições, determina que “Tutti i provvedimenti giurisdizionali devono essere motivati”, Michelle Taruffo (2015, p. 335) afirma que o princípio da obrigatória motivação está inserido no sistema de garantias que as constituições democráticas trouxeram para a tutela das situações jurídicas das pessoas diante do poder

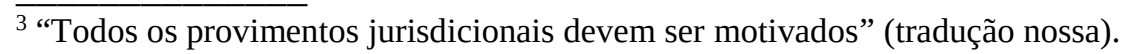


do Estado e, de modo particular, diante das manifestações que esse revela pelo exercício da jurisdição, sendo tal princípio parte das garantias fundamentais de natural justice ${ }^{4}$.

Por isso, as funções democráticas das decisões judiciais como um todo devem ir ao encontro da vontade popular. Não no sentido de que a decisão deve agradar a todos, afinal, é inerente ao litígio a discordância daquele que sucumbe, mas no de que precisa esclarecer, tornar conhecido qual o iter lógico-jurídico trilhado pelo juiz para a conclusão decisória. E desse caminho, em regra, segundo a Constituição Federal, merecem todos serem conhecedores, integrantes ou não da relação jurídicoprocessual na qual foi a decisão proferida.

A norma que dispõe sobre a publicidade das decisões, não por acaso, vem no mesmo inciso em que se determina a obrigatória fundamentação, qual seja, o inciso IX, do art. 93, da CF. Esses dois elementos, erigidos pelo constituinte como princípios constitucionais, são direitos fundamentais das partes e da sociedade. Nessa esteira, sobre a relação entre publicidade e motivação das decisões, descreve Michelle Taruffo (2015, p. 342) que ambas “[...] respondem à mesma exigência política de fundo, que é aquela de instaurar a possibilidade de uma relação direta (e, portanto, ainda de controle) entre a administração de justiça e ambiente social”.

Eis a base das funções da fundamentação: não deixar que o poder de decidir de modo imperativo e definitivo se afaste do poder primário da República, o qual pertence ao povo. A partir daí, é possível descrever uma série de funções que a fundamentação das decisões herda, enquanto elemento democrático, de ordem endoprocessual e extraprocessual.

\subsubsection{Funções endoprocessuais da fundamentação}

Como funções endoprocessuais, revela José Rogério Cruz e Tucci (1989, p. 223) que a fundamentação: a) de modo imediato, funciona ao juiz, antes até que às partes, como instrumento demonstrativo de legitimidade da conclusão jurídica do ato decisório, cujo teor já se revelava ao intuito daquele; b) serve para persuadir a parte sucumbente de que não é resultado de sorte ou do acaso a decisão, mas de atuação legal; e c) permite o controle crítico da exata dimensão volitiva do juiz revelada na decisão e, como corolário, dos limites objetivos do julgado, favorecendo que com maior rigor o órgão ad quem analise a justiça e a legalidade das decisões que lhes são submetidas a exame.

Também no âmbito endoprocessual, Michele Taruffo (2015, passim) aponta que

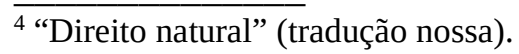


tradicionalmente se encontram razões de diferentes ordens para a fundamentação. Perante as partes, individualiza-se esta em um tríplice aspecto: a) o de persuadir as partes (ou os advogados destas), em especial a sucumbente, de que a decisão foi justa e benigna, bem como de que valorou de modo adequado o juiz as teses contrapostas; b) facilitar o exame da oportunidade de interpor recursos, dado que por meio da fundamentação é possível individualizar-se os vícios da decisão que podem revelar que há razões para recorrer; e c) desempenha o papel de instrumento interpretativo do dispositivo da decisão, favorecendo a adequada individualização e definição do conteúdo do julgado a partir das afirmações do juiz, sendo indispensável à determinação objetiva da pronúncia judicial, a qual necessariamente deve permitir que seja possível se determinar o seu exato conteúdo. E, perante o tribunal, mostra-se necessária para que o juízo ad quem afira melhor a procedência do recurso, já que, analogamente ao que ocorre com as partes perante a decisão, ao juízo recursal a fundamentação funciona como elemento de persuasão e clarificação em relação à procedência e ao exato conteúdo da decisão recorrida, bem como permite que o tribunal verifique objetivamente a existência de vícios que infirmem a decisão atacada e a conexão entre estes e as razões recursais, revelando-se, assim, um fator de racionalização do sistema.

No que tange às funções endoprocessuais da fundamentação perante as partes, é certo que elas não servem apenas para o autor e para o réu, mas funcionam a todos que integrem a relação jurídico-processual em condição diversa de julgador, formulando pretensões, veiculando defesa ou ofertando pareceres, como os terceiros interventores, o Ministério Público e o terceiro prejudicado de que trata o art. 996, do CPC, que possuem legitimidade para recorrer da decisão.

Além disso, tais funções também se aplicam aos advogados das partes, não apenas na condição de patronos, mas para a defesa de direito próprio, no ponto atinente aos honorários advocatícios, os quais, segundo o art. 23 da Lei ${ }^{\circ}$ 8.906/94 (BRASIL, 1994), constituem direito autônomo do advogado. Assim, caso discorde do percentual ou valor arbitrado pelo juiz, por meio da fundamentação para tê-lo feito, o advogado poderá conhecer das razões do valor fixado, verificando, com isso, se houve coerência entre este e os parâmetros elencados nos incisos I a IV, do $\S 2^{\circ}$, do art. 85, do CPC, possibilitando a conclusão sobre a conveniência de interposição de recurso para a majoração dos honorários.

\subsubsection{Funções extraprocessuais da fundamentação}

Na ordem extraprocessual, para José Rogério Cruz e Tucci (1989, p. 224), a fundamentação, do ponto de vista técnico, mostra-se útil ao enriquecimento e uniformização da jurisprudência, 
servindo, assim, como avultado subsídio aos que contribuem para o aperfeiçoamento e aplicação do direito. E, para além da lógica jurídica, funciona como direito fundamental que dá efetividade ao direito de defesa das partes e à independência e imparcialidade do juiz, emergindo como um imperativo do sistema jurisdicional de composição de litígios, elevado à norma de natureza constitucional.

Também no âmbito extraprocessual, Adriano Cesar Felisberto e Celso Hiroshi Iocohama (2010, p. 151) enaltecem que a motivação das decisões judiciais possibilita à sociedade “[...] a garantia de controle de imparcialidade e probidade do Poder Judiciário, convencendo a todos os interessados de que a decisão foi correta e justa.” E Luiz Fernando Coelho (2007, p. 27) diz que a motivação “[...] tem evidente conteúdo político, no sentido de que visa a impedir o julgamento arbitrário, pois o juiz deve provar às partes e aos cidadãos que sua imparcialidade foi preservada, e que a sentença foi justa e na conformidade da lei.”

Essas afirmações doutrinárias coadunam-se e ganham sentido com a norma constitucional que dispõe que todo o poder emana do povo, pois é por essa razão que o juiz deve, como qualquer agente público no exercício da função, submeter-se à vontade popular; e, no caso específico do Poder Judiciário no exercício de sua função típica, essa submissão é revelada por meio de decisões adequadas ao ordenamento jurídico, sendo que a observância a isso só pode ser inequivocamente conhecida por meio da fundamentação, já que, como revela Michelle Taruffo (2015, p. 342), “a publicidade de um dictum oracular seria praticamente inútil”.

Por isso, negar o importante papel extraprocessual da fundamentação das decisões judiciais feriria a essência da democracia e da própria República, já que nesta todo o poder sempre emanará do povo, devendo ser colocados à sua disposição, objetivamente, mecanismos para seu exercício.

\subsection{OS DOIS NÍVEIS OU GRAUS DE JUSTIFICAÇÃO ESSENCIAIS À FUNDAMENTAÇÃO DEMOCRÁTICA}

Querendo eliminar decisões judiciais genéricas, o legislador processual civil de 2015, trazendo as situações dispostas nos incisos I a VI, do art. 489, do atual Código de Processo Civil, reavivou, ainda que sem intenção, uma vetusta técnica de fundamentação que leva em conta a estrutura motivacional, segundo a qual a fundamentação deve ser feita com duplo nível (ou duplo grau) de justificação, as quais propiciarão, em seguida, a afirmação de que a fundamentação exigida pela Constituição Federal é a lato sensu, englobando a fundamentação stricto sensu como espécie. 


\subsubsection{O primeiro nível de justificação da fundamentação: context of discovery ${ }^{5}$}

Esse nível forma-se pelo que se pode denominar de fundamentação stricto sensu. É nele que o juiz exporá a ossatura motivacional essencial em que repousa a decisão. Em linhas gerais, é ele formado pelos motivos fundantes e pela incidência normativa, já que, como descreve Michele Taruffo (2015, p. 238), é nesse nível que são trazidos os enunciados justificativos inerentes às escolhas finais do juiz, sintetizando-se pelo seguinte esquema:

Esquema 1 - Primeiro nível de justificação da fundamentação

$$
(\mathbf{F} \leftarrow \rightarrow \mathrm{N}) \rightarrow \mathbf{Q} \rightarrow \mathbf{C}
$$

Fonte: TARUFFO, Michele. A motivação da sentença civil. Tradução Daniel Mitidiero, Rafael Abreu e Vitor de Paula Ramos. São Paulo: Marcial Pons, 2015, p. 238.

Pela singularidade da descrição sobre o significado dessa representação, feita por Michelle Taruffo, mostra-se preferível, ao explicá-la, trazê-la literalmente. E leciona ele sobre o esquema que:

Esse descreve um conjunto de relações de implicação entre enunciados na seguinte ordem: 1) os enunciados inerentes aos fatos da causa (F) implicam aplicabilidade de determinadas normas (N); 2) ao revés, as normas individualizadas como aplicáveis (N) implicam existência de determinados fatos (F). Na medida em que subsistem ambos os nexos de implicação, realiza-se coincidência semântica entre o suporte fático abstrato e o suporte fático concreto. 3) Essa, de seu turno, implica qualificação (Q) dos fatos apurados segundo as normas declaradas aplicáveis. 4) A qualificação jurídica do suporte fático concreto implica efeitos definidos pelas normas qualificadoras e, portanto, implica conclusão (C) consistente na declaração desses efeitos à relação deduzida no processo (TARUFFO, 2015, p. 238).

Para o bom entendimento da composição do primeiro nível de justificação da fundamentação, segue um exemplo prático. Suponha-se que A ingresse com ação indenizatória em face de B, pedindo que ele lhe pague quantia certa, em razão de B ter sido negligente na condução de veículo automotor, não indicando com antecedência, mediante gesto regulamentar de braço ou luz indicadora de direção do veículo, a mudança de faixa de circulação, e que disso tenha decorrido colisão do veículo dele contra o de A, causando danos a que este quer reparação. Neste caso, conforme o esquema apresentado, o primeiro nível de justificação da fundamentação da decisão, caso o juiz julgue procedente o pedido, por exemplo, será composto pelas seguintes exposições: 1) enunciados que afirmam terem restados provados a colisão alegada, a negligência de B e os danos no veículo de $\mathrm{A}(\mathrm{F})$; 2) enunciados que declaram que os fatos apurados mostram ter B cometido infração à norma de trânsito prevista no art. 196, do Código de Trânsito Brasileiro (N); 3) enunciados que asseveram

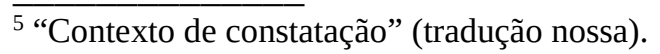


ser a negligência de B qualificada pelo ordenamento jurídico como um ato ilícito, segundo a norma do art. 186, do Código Civil (Q); e 4) enunciados que reconheçam que B deve, por isso, reparar o dano sofrido por A, já que aquele que, por ato ilícito, causar dano a outrem, fica obrigado a reparálo, conforme previsto no caput do art. 927, do Código Civil (C).

Taruffo (2015, p. 17) explica que no primeiro nível de justificação o raciocínio do julgador é decisório (context of discovery), traduzindo-se no "procedimento com o qual o juiz formula a decisão final, mediante uma concatenação de escolhas, de hipóteses afastadas ou confirmadas, de mudanças que intervêm no curso do processo, de elaboração e valoração que desencadeiam na decisão final”.

Pelo que se apreende da lição acima, o primeiro nível de justificação traz a explicitação dos fatos que o juiz entendeu serem verdadeiros, invariavelmente obtidos pela análise das provas trazidas aos autos, ou seja, o “F” representa a exposição dos motivos fundantes da decisão. Ademais, está nesse primeiro grau contida a descrição das normas que se aplicarão ao caso concreto, quer dizer, o “N” revela-se a incidência normativa.

Já a qualificação (Q), decorrente da relação binômica fato-norma, e a conclusão (C), revelada pela declaração dos efeitos da interação trinômica fato-norma-qualificação, representam um ponto de intersecção entre a fundamentação e o dispositivo da decisão, sendo verdadeiro exaurimento daquela, essencial ao entendimento lógico-jurídico da parte dispositiva do ato decisório, pois tanto a qualificação quanto os efeitos se manifestarão no julgamento. "Q” e “C” são, pois, o mais próximo contato entre a fundamentação e o dispositivo, manifestando-se como a passagem do raciocínio fundamentatório ao decisório, já que deles decorrerão diretamente a procedência ou improcedência do pedido, o deferimento ou indeferimento do requerimento, a concessão ou denegação da ordem, o provimento ou desprovimento do recurso, etc.

\subsubsection{O segundo nível de justificação da fundamentação: context of justification ${ }^{6}$}

Manifesta-se o primeiro nível de justificação, em síntese, por conclusões de ordem fática e normativa e, a partir da conclusão normativa, decorrem conclusões qualificativas e consequenciais. Todas estas têm em comum o fato de não abarcarem os motivos pelos quais o juiz a elas chegou, ou seja, o primeiro nível contém apenas os motivos fundantes e a incidência normativa, que formam a ratio decidendi do ato decisório, mas nele não estão contidos os obiter dicta, os quais, como já

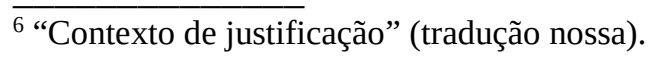


abordado neste artigo, são componentes essenciais da motivação ${ }^{7}$ e, por consequência, da fundamentação lato sensu.

O primeiro nível de justificação forma-se pela fundamentação stricto sensu, pela ratio decidendi, enquanto o segundo nível é composto pelos obiter dicta. Este último será estritamente explicativo, servindo de suporte racional, tendo função de indicar o iter lógico das escolhas adotadas no primeiro nível.

À fundamentação democrática não basta a existência apenas do primeiro nível de justificação, já que ele não é, por si só, suficiente para possibilitar o controle interno e externo das decisões judiciais. A decisão com apenas um nível de justificação é arbitrária, pois a mera exposição das conclusões acerca dos fatos, das normas a serem aplicadas e da qualificação e consequência jurídica decorrentes dessa aplicação, torna inviável o entendimento sobre a racionalidade das escolhas do juiz. É preciso que sejam justificadas cada uma dessas conclusões.

É no segundo nível de justificação que se encontram os motivos pelos quais o juiz chegou à conclusão acerca dos fatos, dos porquês de a estes incidirem tais normas e por quais razões da relação fato-norma decorrem as qualificações e conclusões expressas no primeiro nível.

Michele Taruffo traça o esquema dos dois níveis de justificação da seguinte forma, trazendo sua explicação:

Esquema 2 - Duplo nível de justificação da fundamentação

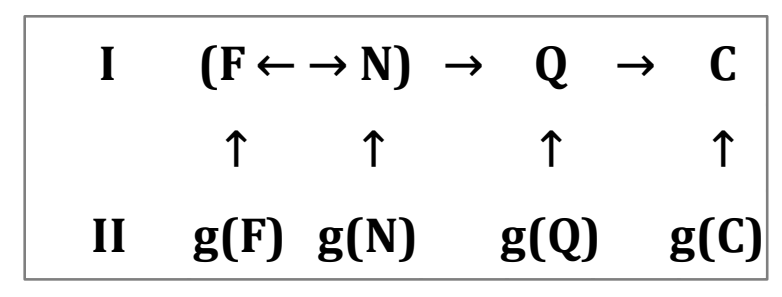

Fonte: TARUFFO, Michele. A motivação da sentença civil. Tradução Daniel Mitidiero, Rafael Abreu e Vitor de Paula Ramos. São Paulo: Marcial Pons, 2015, p. 242.

O primeiro nível (I) diz respeito à estrutura lógica dos enunciados inerentes ao contexto em que se exprime a decisão. O segundo nível (II) concerne à justificação inerente a qualquer um dos enunciados em si considerados. [...]. O significado dos símbolos que comparecem ao nível II pode ser assim definido: $g(F)$ indica a justificação da apuração dos fatos; g(N) indica a justificação da escolha da norma aplicável e sua respectiva interpretação; g(Q) indica a justificação da qualificação jurídica de F segundo N e tem uma importância na medida em que também a subsunção implica escolhas autônomas; $g(C)$ indica, por fim, a justificação da decisão a respeito do efeito jurídico inerente ao suporte fático (TARUFFO, 2015, p. 242).

Pela explanação acima, no caso do exemplo prático citado na explicação acerca do primeiro

\footnotetext{
${ }^{7}$ Cf., nesse sentido, a subseção 1.1.
} 
nível de justificação, para cumprir adequadamente o segundo nível de justificação, deverá então o juiz justificar expressamente os motivos de ter chegado à conclusão: 1) de que houve a colisão alegada; 2) de que esta foi causada por negligência de B; 3) de que realmente disso decorreram os danos no veículo de A; 4) de que B cometeu infração à norma de trânsito prevista no art. 196, do Código de Trânsito Brasileiro; 5) de por que os fatos, de acordo com a norma violada, devem ser qualificados como um ato ilícito; e 6) de que a conduta de B implica o dever de reparar os prejuízos sofridos por A.

Como explica Taruffo (2015, p. 17), diferentemente do que ocorre no primeiro nível de justificação, no segundo nível o juiz exerce raciocínio justificativo (context of justification), no qual, “[...] depois de ter formulado a decisão final, [...] expõe as 'boas razões’ em função das quais sua decisão deve ser aceita como válida e compartilhável”.

Por isso, todas as justificativas apontadas devem estar contidas na fundamentação exemplificada, sob pena de não possibilitar que a decisão seja contestada em seu conteúdo, já que não se mostrarão explicadas as escolhas do juiz.

\subsection{FUNDAMENTAÇÃO EM SENTIDO ESTRITO E EM SENTIDO AMPLO E O CONCEITO DE DECISÃO FUNDAMENTADA}

Foi visto que uma análise sistemática da Constituição, mormente quanto às funções que a fundamentação exerce, indica que o alcance da exigência de fundamentação das decisões judiciais é amplo, abarcando tanto a obrigação da exposição do raciocínio decisório quanto do justificativo por parte do juiz, ou seja, a fundamentação constitucional, atendendo aos ideais democráticos e republicanos do Estado brasileiro, é a que obriga e abriga a exposição da fundamentação com duplo nível de justificação.

Essa amplitude irredutível do conteúdo mínimo da fundamentação democrática impõe uma construção conceitual sobre fundamentação, cindindo-se o conceito daquela em fundamentação stricto sensu e fundamentação lato sensu ou democrática, e relacionando-os ao conceito de motivação.

A distinção basilar entre motivação e fundamentação stricto sensu é que enquanto a primeira é composta pelos obiter dicta e pelo motivo fundante, a segunda compõem-se do motivo fundante e da incidência normativa ${ }^{8}$.

Já a fundamentação lato sensu ou democrática é gênero, do qual a motivação e a

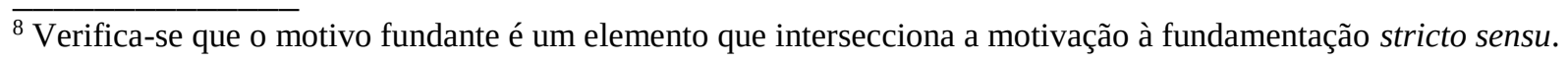


fundamentação stricto sensu são espécies, estando as duas últimas inseridas na primeira. E é daquela fundamentação, a lato sensu, que trata a norma do inciso IX, do art. 93, da CF, e nela estão contidos todos os atos formais de índole motivacional essenciais a qualquer ato decisório, ou seja, a fundamentação lato sensu ou democrática é composta pela exposição dos obiter dicta, dos motivos fundantes e da incidência normativa, já que ela deve necessariamente ser feita com duplo nível de justificação.

Os incisos I a VI, do $\S 1^{\circ}$, do art. 489, do $\mathrm{CPC}^{9}$, têm o objetivo notório de guiar os magistrados a não falharem em cumprir o constitucional dever de fundamentarem suas decisões com duplo nível de justificação. Nesse sentido, Fredie Didier Jr., Paula Sarno Braga e Rafael Alexandria de Oliveira (2016, p. 334), reconhecendo a importância dessa nova disposição normativa processual, ressaltam que já era possível se extrair o mesmo conteúdo do dever de fundamentar expresso na Constituição Federal.

No inciso I do rol normativo em questão, a preocupação do legislador é com a decisão que não apresenta nenhum obiter dictum nem o motivo fundante, limitando-se à indicação da incidência normativa. Esse tipo de decisão nem ao menos é provido de fundamentação stricto sensu, já que até a ratio decidendi está incompleta. Em suma, é o caso em que o juiz nem sequer explicita seu raciocínio decisório de modo satisfatório, ocorrendo vício na fundamentação já nas justificativas referentes ao primeiro nível de justificação. Tal situação viola o dever de fundamentação, pois, como revela Daniel Amorim Assumpção Neves (2017, p. 186) em comentário sobre tal inciso, cabe ao juiz “expor em seu pronunciamento decisório a interpretação que fez da norma jurídica aplicável ao caso concreto e a correlação entre elas e os fatos do caso concreto”.

A lei processual, no inciso II, do $\S 1^{\circ}$, do art. 489, do CPC, enaltece a nulidade da decisão que não traz obiter dicta suficientes a deixar claro se o magistrado realmente enfrentou os fatos do caso concreto lhe colocado a julgamento. Os conceitos jurídicos indeterminados previstos nas normas do ordenamento (como, v.g., "boa-fé”, “justo título”, “considerável número de pessoas” e “extensa área”) devem ser concretizados pelo juiz no ato decisório, sob pena de não ficar evidenciado se há consonância entre a incidência normativa e os motivos da decisão. Conforme os ensinamentos de

\footnotetext{
9 “§ $1^{\circ}$ Não se considera fundamentada qualquer decisão judicial, seja ela interlocutória, sentença ou acórdão, que: I - se limitar à indicação, à reprodução ou à paráfrase de ato normativo, sem explicar sua relação com a causa ou a questão decidida; II - empregar conceitos jurídicos indeterminados, sem explicar o motivo concreto de sua incidência no caso; III - invocar motivos que se prestariam a justificar qualquer outra decisão; IV - não enfrentar todos os argumentos deduzidos no processo capazes de, em tese, infirmar a conclusão adotada pelo julgador; V - se limitar a invocar precedente ou enunciado de súmula, sem identificar seus fundamentos determinantes nem demonstrar que o caso sob julgamento se ajusta àqueles fundamentos; VI - deixar de seguir enunciado de súmula, jurisprudência ou precedente invocado pela parte, sem demonstrar a existência de distinção no caso em julgamento ou a superação do entendimento.”
} 
Luiz Guilherme Marinoni, Sérgio Cruz Arenhart e Daniel Mitidiero (2015, p. 492-493), o legislador, ao utilizar-se de termos dessa ordem, faz um verdadeiro pedido para que o juiz colabore no aclaramento dos limites do termo vago, sendo preciso “mostrar com qual significado ele é empregado, por que razão serve para disciplina do caso concreto e quais os efeitos jurídicos que dele são extraídos.” Assim como todo vício na fundamentação, a falha formal que deriva de o magistrado não realizar tal concretização mostra-se um fator que impede o exame concludente acerca do adequado raciocínio do juiz quanto ao direito aplicado ao caso concreto.

O inciso III, do $\S 1^{\circ}$, do art. 489, do CPC, deixa claro ser uma afronta ao princípio constitucional da obrigatória fundamentação a decisão que traz obiter dicta falaciosos, resultantes de uma motivação abstrata, que não é apta a concretizar a norma à causa sub judice. Em regra, é sobre os motivos acessórios que tratam dos fatos que esse vício recai, já que, por mais semelhante que um caso seja em relação a outro, na ordem dos fatos sempre há especificidades únicas em cada situação levada a julgamento, não sendo possível, portanto, o juiz tratar daqueles especificamente antes de realmente conhecer o processo e suas provas. Nessa linha, a exigência contida nesse inciso III, nas palavras de Elpídio Donizetti (2017, p. 706), existe porque “é fundamental que as decisões judiciais estejam coerentes com os fatos apresentados pelas partes. A fundamentação do julgado não pode se mostrar incompreensível ou contraditória, ao ponto de gerar dúvida acerca da conclusão apresentada pelo magistrado".

Com o inciso IV do citado rol normativo, o papel do juiz no contraditório fica evidenciado. Especificamente, essa norma mostra a intenção de a lei processual deixar clara a obrigação de que na fundamentação estejam expostos os obiter dicta, porquanto, de acordo com o previsto em seu texto, expressamente o ordenamento jurídico não aceita como válida a decisão que apenas explicita a ratio decidendi, trazendo somente os motivos fundantes e a incidência normativa, sem apresentar todos os obiter dicta que deveria, cuja função é justamente a de deixar claro que a ratio decidendi não foi obtida sem a avaliação de todos os fatores que são aptos a, em tese, infirmá-la.

Comentando esse inciso IV e enfatizando a importância da questão, asseveram Luiz Guilherme Marinoni, Sérgio Cruz Arenhart e Daniel Mitidiero (2015, p. 493) que “a norma jurídica é fruto de uma colaboração entre o legislador e o juiz, de modo que a sociedade civil tem o direito não só de influir no momento da sua formação legislativa, mas também no momento da sua reconstrução jurisdicional.”

Sobre o inciso V, explica Elpídio Donizetti (2017, p. 708) que com ele o CPC visa a “evitar as decisões meramente repetitivas de julgados, jurisprudências ou enunciados de súmulas, que não demonstrem a aplicabilidade do entendimento consolidado ao caso efetivamente apreciado", sendo 
isso necessário para que o dever de fundamentação reflita de modo efetivo o que foi reproduzido no processo. E o inciso VI, também nos dizeres daquele doutrinador, revela que o julgador, na fundamentação, ao indicar os porquês de ter aplicado determinado entendimento à lide posta sob sua apreciação, "também deve justificar a inadequação de precedente, súmula ou jurisprudência quando a parte a invocar como forma de subsidiar seu pleito” (DONIZETTI, 2017, p. 708-709).

Tendo em vista o conteúdo mínimo da fundamentação das decisões judiciais no ordenamento jurídico brasileiro, traduzido pelo que se pode chamar de fundamentação lato sensu, democrática ou com duplo nível de justificação, e observando-se o que dispõem os incisos I a VI, do § $1^{\circ}$, do art. 489, do CPC, pode-se conceituar decisão fundamentada como sendo aquela que, sem deixar de enfrentar todos os argumentos deduzidos no processo capazes de, em tese, infirmar a ratio decidendi, explica a relação das normas aplicadas com o caso concreto, indicando as justificativas de suas incidências e definindo eventuais conceitos jurídicos indeterminados.

Consonante às argumentações trazidas, apresenta-se a seguir esquema e quadro ilustrativo da fundamentação lato sensu, democrática ou com duplo nível de justificação:

Esquema 3 - Fundamentação lato sensu, democrática ou com duplo nível de justificação

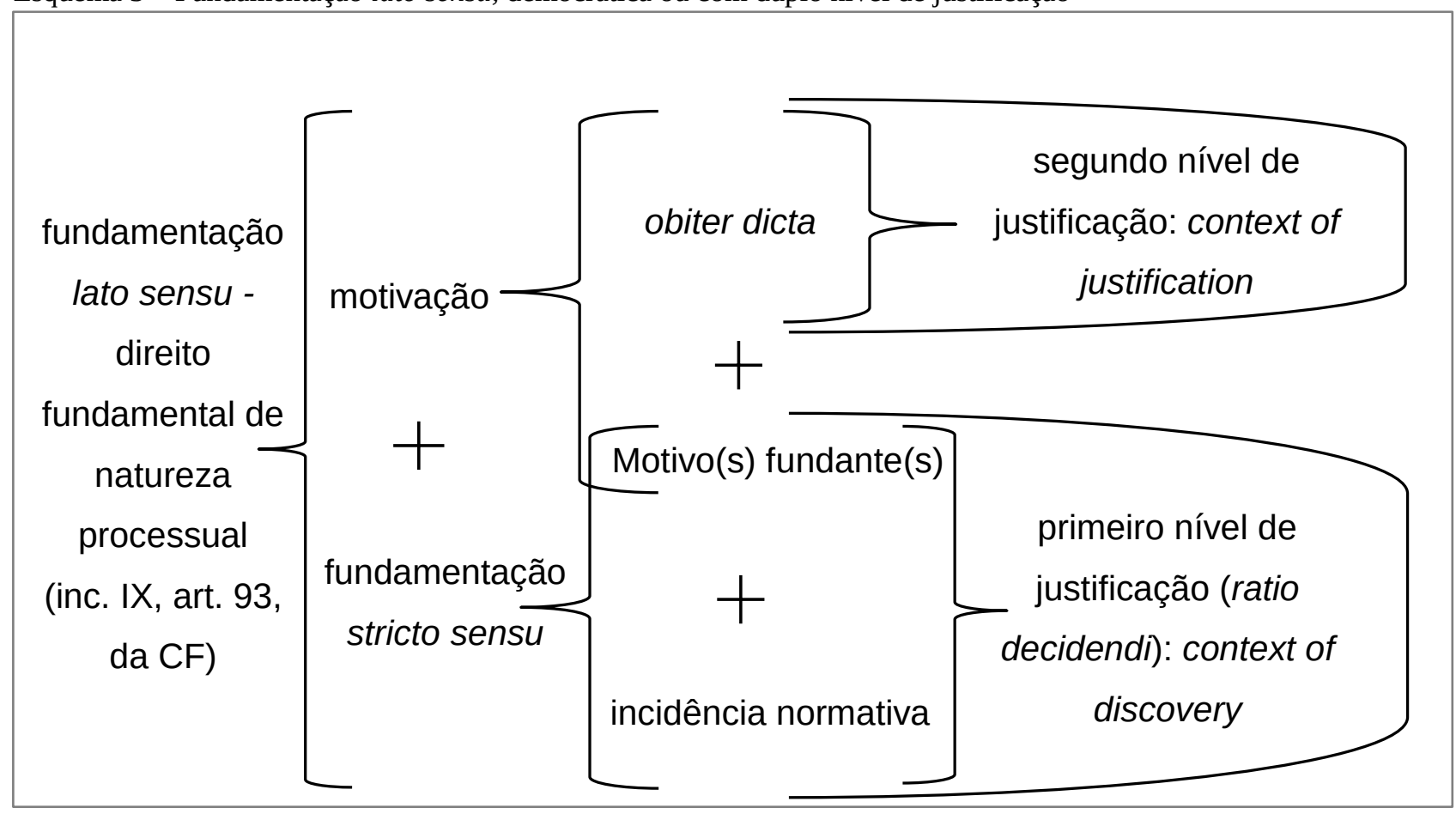

Fonte: os autores. 
Quadro 2 - Relação entre os conceitos e elementos envolvendo a fundamentação lato sensu, democrática ou com duplo nível de justificação

\begin{tabular}{|l|l|}
\hline \multicolumn{1}{|c|}{$\begin{array}{c}\text { Conceitos inerentes à fundamentação } \\
\text { democrática }\end{array}$} & \multicolumn{1}{c|}{ Elementos que os compõem } \\
\hline Fundamentação lato sensu & $\begin{array}{l}\text { Composta pela motivação e pela } \\
\text { fundamentação stricto sensu }\end{array}$ \\
\hline Motivação & $\begin{array}{l}\text { Composta pela exposição dos obiter dicta } \\
\text { e do(s) motivo(s) fundante(s) }\end{array}$ \\
\hline Fundamentação stricto sensu & $\begin{array}{l}\text { Composta pelo motivo(s) fundante(s) e } \\
\text { pela(s) norma(s) incidente(s), que formam } \\
\text { a ratio decidendi }\end{array}$ \\
\hline Ratio decidendi & $\begin{array}{l}\text { Composta pelo motivo(s) fundante(s) e } \\
\text { pela(s) norma(s) incidente(s); os dizeres } \\
\text { expostos na ratio decidendi compõem a } \\
\text { fundamentação stricto sensu }\end{array}$ \\
\hline $\begin{array}{l}\text { Primeiro nível de justificação (context of of } \\
\text { discovery) }\end{array}$ & $\begin{array}{l}\text { Parte da fundamentação composta pelos } \\
\text { dizeres que revelam raciocínios decisórios, } \\
\text { ou seja, pela ratio decidendi. Desse modo, } \\
\text { no primeiro nível de justificação encontra- } \\
\text { se a fundamentação stricto sensu }\end{array}$ \\
\hline $\begin{array}{l}\text { Segundo nível de justificação (context of } \\
\text { justification) }\end{array}$ & $\begin{array}{l}\text { Parte da fundamentação composta } \\
\text { exclusivamente pelos dizeres que } \\
\text { funcionam como obiter dicta }\end{array}$ \\
\hline
\end{tabular}

Fonte: os autores.

\section{CONCLUSÃO}

Motivação e fundamentação são questões formais, procedimentais, obrigatoriamente presentes em qualquer decisão judicial. A análise de sua adequação não envolve o mérito da questão sub judice, mas o antecede. A ausência destes requisitos poderá levar o órgão ad quem a anular a decisão impugnada, já que se trata de error in procedendo ${ }^{10}$. Terá o órgão a quo, neste caso, ou não exposto o iter lógico por ele realizado para afastar determinados argumentos e acatar outros que resultaram na aplicação do direito (vício na motivação) ou, ainda que o tenha feito, deixado de explicitar a ratio decidendi (vício na fundamentação).

No que tange especificamente ao termo fundamentação, é certo que este deve ser entendido sob duas perspectivas: fundamentação lato sensu e fundamentação stricto sensu. A fundamentação stricto sensu é aquela que caminha paralelamente à motivação, sendo a esta interseccionada pela exposição dos motivos fundantes; é, em resumo, a explicitação da ratio decidendi, que é formada

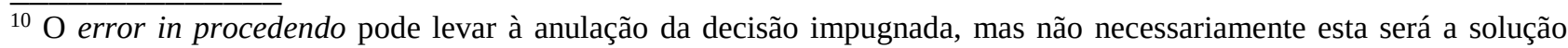
adotada pelo órgão ad quem, que, valendo-se da previsão do art. 282, § 2º do CPC, não pronunciará a nulidade, nem mandará repetir o ato ou suprir-lhe a falta, se puder decidir o mérito a favor da parte a quem aproveitaria a decretação da nulidade.
} 
pelos motivos fundantes e pela incidência normativa.

É da fundamentação lato sensu ou democrática que trata a norma do inciso IX, do art. 93, da CF, e nela estão contidos todos os atos formais de índole motivacional essenciais a qualquer ato decisório; ou seja, a fundamentação lato sensu ou democrática é composta pela exposição dos obiter dicta, dos motivos fundantes e da incidência normativa, já que ela deve necessariamente ser feita com duplo nível de justificação. Portanto, se por um lado a motivação e a fundamentação stricto sensu revelam-se coisas distintas, apesar de interseccionadas, por outro, a fundamentação lato sensu ou democrática é o gênero do qual aquelas são espécies, já que ambas estão nela contidas.

O Código de Processo Civil que entrou em vigor em 2016 trouxe seis incisos que completam o $\S 1^{\circ}$, do seu art. 489, os quais formam um grupo de normas que não inovaram o ordenamento jurídico, pois elas já eram decorrência lógica do princípio constitucional da obrigatória fundamentação, previsto no inciso IX, do art. 93, da CF, a que objetivam dar efetividade, trazendo exemplos de decisões nulas por vício na fundamentação, seja por falha na exposição dos motivos secundários (obiter dicta), dos motivos fundantes ou da incidência normativa.

Os princípios da razoável duração do processo e da eficiência podem funcionar como limitadores da obrigatória fundamentação. Mostra-se relevante que o magistrado dê efetividade ao direito material discutido na causa sub judice, dando importância à duração razoável do processo e sendo eficiente em sua gestão. Contudo, não pode o juiz, sob o manto de tais princípios, proferir decisão sem fundamentação adequada às exigências do ordenamento jurídico, pois se agir dessa forma estará eliminando um princípio componente do devido processo legal, assim como os primeiros o são.

A saída para o caso é o juiz agir com ponderação, usando como parâmetros as situações previstas nos incisos I a VI, do $\S 1^{\circ}$, do art. 489, do CPC, para que não incorra nos vícios ali constantes, que se resumem em fundamentação genérica; mas que, também, não perca excessivo tempo dizendo coisas que extrapolam demasiadamente o necessário a afastar todos os argumentos deduzidos no processo capazes de, em tese, infirmar a conclusão adotada. Ou seja, sem suprimir as essenciais justificativas que devem compor a fundamentação na função de obiter dicta, deve o julgador prezar também pela razoável duração do processo e pela eficiência processual.

\section{REFERÊNCIAS}

BRASIL. CONSELHO NACIONAL DE JUSTIÇA. Justiça em números 2017: ano-base 2016. Brasília: CNJ, 2017. Disponível em: <https://goo.gl/9fLFmZ>. Acesso em: 4 set. 2017. 
BRASIL. Constituição da República Federativa do Brasil, de 5 de outubro de 1988. Diário Oficial da União, Brasília, 1988. Disponível em: <https://goo.gl/qEEPFQ>. Acesso em: 10 dez. 2017.

BRASIL. Escola Nacional de Formação e Aperfeiçoamento de Magistrados. Seminário - O Poder Judiciário e o novo CPC: enunciados aprovados. 2015. Disponível em: <https://goo.gl/V3jpcj>. Acesso em: 11 dez. 2017.

BRASIL. Lei n ${ }^{\circ}$ 10.259, de 12 de julho de 2001. Diário Oficial da União, Brasília, 2001. Disponível em: <https://goo.gl/3GzoY>. Acesso em: $10 \mathrm{dez} .2017$.

BRASIL. Lei n ${ }^{\circ}$ 13.105, de 16 de março de 2015. Diário Oficial da União, Brasília, 2015. Disponível em: <https://goo.gl/6b0EbE>. Acesso em: 10 dez. 2017.

BRASIL. Lei nº 8.009, de 29 de março de 1990. Diário Oficial da União, Brasília, 1990. Disponível em: <https://goo.gl/XIvl2C>. Acesso em: $10 \mathrm{dez} .2017$.

BRASIL. Lei $n^{\circ}$ 8.906, de 4 de julho de 1994. Diário Oficial da União, Brasília, 1994. Disponível em: <https://goo.gl/R3lGd>. Acesso em: 10 dez. 2017.

BRASIL. Lei $\mathrm{n}^{0}$ 9.099, de 26 de setembro de 1995. Diário Oficial da União, Brasília, 1995. Disponível em: <https://goo.gl/woI1b>. Acesso em: 10 dez. 2017.

BRASIL. Superior Tribunal de Justiça. Voto no REsp nº 706.769 / RN. Relator: Ministro Luis Felipe Salomão. Brasília, 12 mar. 2009. Diário da Justiça Eletrônico. Disponível em: <https://goo.gl/YMFYQ6>. Acesso em: 11 dez. 2017.

COELHO, Luiz Fernando. Dogmática e crítica da prova no processo. Revista de Processo, São Paulo, ano 32, v. 154, p. 22-36, dez. 2007.

DELGADO, Márcia. AMB, Anamatra e Ajufe pedem vetos ao novo CPC. 2015. Disponível em: $<$ https://goo.gl/kpxATF>. Acesso em: 3 ago. 2016.

DIDIER JÚNIOR, Fredie. Sobre a fundamentação da decisão judicial. [São Paulo], 2012. Disponível em: <https://goo.gl/WIpkZ7>. Acesso em: 27 jan. 2016.

DIDIER JÚNIOR, Fredie; BRAGA, Paula Sarno; OLIVEIRA, Rafael Alexandria de. Curso de Direito Processual Civil. 11. ed. v. 2. Salvador: JusPodivm, 2016.

DIDIER JÚNIOR, Fredie; CUNHA, Leonardo Carneiro da; BRAGA, Paula Sarno; OLIVEIRA, Rafael Alexandria de. Curso de Direito Processual Civil. 13. ed. v. 3. Salvador: JusPodivm, 2016.

DONIZETTI, Elpídio. Curso didático de direito processual civil. 20. ed. São Paulo: Atlas, 2017.

FELISBERTO, Adriano Cesar; IOCOHAMA, Celso Hiroshi. O princípio da motivação nas decisões judiciais de segunda instância dos juizados especiais cíveis. Revista de Processo, São Paulo, ano 35, v. 190, p. 127-153, dez. 2010.

GONÇALVES, Marcus Vinicius Rios. Direito processual civil esquematizado. Coordenação Pedro Lenza. 7. ed. São Paulo: Saraiva, 2016. 
GRINOVER, Ada Pellegrini. A Constituição e a invalidade dos atos processuais. Revista de Direito Constitucional e Internacional. São Paulo, ano 1, v. 1, p. 227-236, out. 1992.

ITÁLIA. Constituzione della Repubblica Italiana. Roma: Senato della Repubblica, 2012. Disponível em: <https://goo.gl/daCMbk>. Acesso em: 10 dez. 2016.

MARINONI, Luiz Guilherme; ARENHART, Sérgio Cruz; MITIDIERO, Daniel. Novo Código de Processo Civil Comentado. São Paulo: Revista dos Tribunais, 2015.

MARINONI, Luiz Guilherme; ARENHART, Sérgio Cruz; MITIDIERO, Daniel. Uma nova realidade diante do projeto de CPC: a ratio decidendi ou os fundamentos determinantes da decisão. 2012. Disponível em: <https://goo.gl/XJuRJX>. Acesso em: 6 mar. 2018.

NERY JUNIOR, Nelson; NERY, Rosa Maria de Andrade. Comentários ao código de processo civil. São Paulo: Revista dos Tribunais, 2015.

NEVES, Daniel Amorim Assumpção. Manual de direito processual civil. 9. ed. Salvador: JusPodivm, 2017.

SCHMIDT, Paulo Luiz. Anamatra reage a críticas sobre vetos propostos ao Novo Código de Processo Civil. 2015. Disponível em: <https://goo.gl/ast4yK>. Acesso em: 3 ago. 2016.

SILVA, José Afonso da. Aplicabilidade das Normas Constitucionais. 7. ed. São Paulo: Malheiros, 2009.

TARUFFO, Michele. A motivação da sentença civil. Tradução Daniel Mitidiero, Rafael Abreu e Vitor de Paula Ramos. São Paulo: Marcial Pons, 2015.

TUCCI, José Rogério Cruz e. Ainda sobre a nulidade da sentença imotivada. Revista de Processo, São Paulo, ano 14, v. 56, p. 223-233, out. 1989.

WAMBIER, Teresa Arruda Alvim. A influência do contraditório na convicção do juiz: fundamentação de sentença e de acórdão. Revista de Processo, São Paulo, ano 34, v. 168, p. 53-65, fev. 2009a.

WAMBIER, Teresa Arruda Alvim. Estabilidade e adaptabilidade como objetivos do direito: civil law e common law. Revista de Processo, São Paulo, ano 34, v. 172, p. 121-174, jun. 2009b.

Antônio Rogério Lourencini Graduado e Mestrando em Direito pela Universidade Estadual Paulista 'Júlio de Mesquita Filho’ (Unesp). Oficial de Promotoria no Ministério Público do Estado de São Paulo. E-mail: rogeriolourencini@hotmail.com

Yvete Flávio da Costa Graduada em Direito pela Universidade Federal Fluminense, Mestre e Doutora em Direito pela Pontifícia Universidade Católica de São Paulo. Realizou Pós-Doutoramento na Universidade de Coimbra (Portugal). Professora Assistente na Universidade Estadual Paulista ‘Júlio de Mesquita Filho’ (Unesp). E-mail: yvetecosta@gmail.com 